UDC 159.922.8

https://doi.org/10.31392/NPU-nc.series12.2020.9(54).05

\title{
PSYCHOLOGICAL PECULIARITIES OF THE INTERPERSONAL INTERACTION IN ADOLESCENCE
}

\author{
Larysa Zhuravlova
}

Doctor of Sciences in Psychology, professor, Head of the Department of Developmental Psychology and Consultancy

Zhytomyr Ivan Franko State University

40, Velyka Berdychivska Str., Zhytomyr, Ukraine, 10001

lpz2008@ukr.net, https://orcid.org/0000-0003-4020-7279

\section{Tetiana Kolomiiets}

PhD in Psychology, Associate Professor, Associate Professor of the Department of Developmental Psychology and Consultancy

Zhytomyr Ivan Franko State University

40, Velyka Berdychivska Str., Zhytomyr, Ukraine, 10001

tvkolomiets@ukr.net,http://orcid.org/0000-0002-6883-8796

Oksana Shmygliuk

Lecturer of the Department of the Developmental Psychology and Consultancy

Zhytomyr Ivan Franko State University

40, Velyka Berdychivska Str., Zhytomyr, Ukraine, 10001

shmyglyuk.oksana@gmail.com,http://orcid.org/0000-0002-3334-8033

\begin{abstract}
The aim of the research is to investigate the psychological characteristics of youth's behavior in the context of interpersonal interaction. Theoretical, empirical and statistical methods have been applied for the realization of the research tasks. The main results of empirical research of behavioral activity, affectation and manifestations of youth's dominance in the situation of interpersonal interaction are presented in the article. Their age, gender and dynamic characteristics have been analyzed.

As a result of the empirical research,it was defined that the most of modern youth does not show a great interest in establishing interpersonal contacts. Age dynamics of interpersonal interaction was found and its gender characteristics were analyzed. The period from the teen-age to adulthood there is a decrease in the level of social contacting of young people. This dynamics is typical for boys more than girls. It is stated that a higher level of the interpersonal activity is peculiar for young boysin the adolescence. As for young girls, they are more active in the adulthood.It is noted that young people of the adolescence expresstheir emotions in the process of interpersonal interaction differently: frompathological emotionality tocomplete indifference. The tendency of increasing pathological indicators of emotionality in the interaction during the period of adulthood is analyzed. This dynamics is more common for male representatives compared to females. The empirical study proves that there is an adequate level of emotional activity for boys, and for young girls it is high. It is established thatthemajority of modern youth
\end{abstract}


tends to satisfy their own need of dominance in the process of the interaction with others. In the early adolescence characteristics of dominant behavior are much more frequent than in the late one, and boys are inferior to girls in the level of dominance.

Keywords: adolescence, affectation of the interpersonal interaction, dominance, contact, interpersonal interaction.

\section{Introduction}

Human life cannot be imagined beyond the limits of the interpersonal interaction. A person gets into huge amount of interpersonal interactions every day. All of them form a certain system, which sets its direction of the personality development at various stages of ontogenesis and the measure of its psychological comfort and emotional well-being.

Nowadays artificial intelligence becomes an integral part of human existence and cyberspace acquires the status of a socialization environment, so these facts define the topicality of the study of the interpersonal interaction. The most interesting category in this context is the modern youth, whose representatives are born and live in the era of technology and robotics. Under these conditions, one of the top-priority directions of scientific search is the investigation of the social contact of the young personality, the identification of the transformations experienced by its system of interpersonal relations, and the role of the ot her.

The problem of the interpersonal interaction is not new in psychology, but it is widely researched. Thus, a number of psychological researches is devoted to the study of various aspects of the interpersonal interaction. Particularly, the phenomenological and structuraldynamic characteristics of the processes of the interaction and communication are observed in the works of B. Ananiev (1980), O. Bodalov (1982), S. Bratchenko (1997), H. Kostiuk (1988), O. Leontiev (1997), B. Lomov (1984), V. Myasishchev (1995), M. Obozov (1990), A. Petrovskyi (1982), S. Rubinschtein (1973), N. Sardzhwelladze (1989), V. Semichenko (1998) and etc. The role and importance of the age and individual peculiarites of the interpersonal relationships were studied by M. Boryshevskyi (1974), L. Buieva (1967), Ia. Kolominskyi (2001), I. Kon (1980), D. Feldshtein (1995). An invaluable contribution to the conceptualization of this phenomenon was made by foreign scholars such as M Argyle (1994), E. Aronson (1998), W. G. Bennis (1968), E. Heider (1958), Dzh. Mid (2007), K. Rodzhers (1962), Z. Freud (1963), E. From (1941), Dzh. Homans (1984) and etc.

According to I. Budur, «Every individual in his development feels the need to be a personality - to see himself/herself in the life of other people, continuing their existence with them, and shows the ability to be the personality, implemented in socially significant activities» (Будур, 2009).The subjective sense of happiness mostly depends on the character of the interpersonal interaction (its constructiveness, harmony, efficiency, etc.). Therefore, the problem of finding new ways of the interpersonal interaction optimization is particularly relevant. Such priority shifts accentstowards the subjectification of this phenomenon. In this context, it is advisable to consider the specificage peculiarites of the interpersonal interaction.

Thus, the aim of our research is to study the peculiarities of the behavior of the modern youth in the interpersonal interaction situations. Tasks of the research: 1) to carry out a theoretical analysis of the psychological conditions of interpersonal interaction in adolescence; 2) to select psychodiagnostic tools and to conduct empirical research of behavioral 
manifestations of interpersonal interaction of young people; 3) to carry out the analysis of the received results taking into account sexual characteristics and age dynamics.

\section{Research methods}

A person interacts with another person even still being in the mother's womb (Самоукина, 2000). Of course, this can not be considered a full-fledged interpersonal interaction, as the child in the period of his prenatal development is not yet a person. However, there are researches who demonstrate an impact of such interaction on the further development of the child (Verny \& Kelly, 1981). Since the identification of such influence was not the aim of our work, and we cannot confirm or decline it, we leave this assertion as the hypothetically possible. Shortly after birth, the child begins to master the elementary ways of the interaction with the adults. These includes a reaction of concentration that arise during the contact with adults in the first days of the life, and later - an exhilaration. Usually the circle of the child's interaction in this period is limited to the family.

Throughout the process of socialization (playground, kindergarten, elementary school), the circle of communication of the child expands. It includes new ways and forms of the interaction. Mostly they occur in the form of interpersonal interactions and relationships. Interpersonal relationships are usually tied up within family ties.

According to the I. Kon (KоH, 1979), social priorities of the personality change in the teen-age, which lasts from 11-12, to 14-15 years. Although this period remains as the stage of primary socialization, the problem of the interpersonal interaction becomes particularly acute. According to the unanimous position of the scholars, this age period is mainly characterized by the feeling of adulthood. It most likely that this feeling causes the person's aspiration to change the social roles and the expansion of the field of its interpersonal interaction. Therefore, the leading activity of the teen-age considers intimate-personal communication with peers which remains relevant in the period of youth.

In the domestic psychology the adolescence is divided into two periods: early youth (1415-18 years) and mature youth (18-21-23 years) (Кулагина, 2001). I. Kon calls this life period as «third world» that exists between childhood and adulthood. The adolescence is the final stage of both biological aging and primary socialization. This period is charachterized by a professional, life and social self-determination (Божович, 1968), rethinking of the worldview and a vital position, developsreflection and the self-conception. There is also a gradual stabilization in the emotional sphere, which expresses itself in the emergence of equilibrium and selectivity. Moral development is characterized by the transition from conventional to autonomous morality. As for the volitional sphere - the level of self-regulation and self-control is increasing.

According to the I. Bech, in early youth, unfolding socialization takes place, the person turns into a developed subject and takes over social experience, makes him his own property (Бex, 2008). Expansion of the circle of person-significant relationships is connected with the development of so-called «higher feelings». The assimilation of certain systems of moral norms and principles turns into a complex gamut of different kinds of moral feelings (Кон, 1979; Ináncsi, Láng \& Bereczkei, 2015). According to M. Boryshevskyi (Боришевський, 1992), during this period, the person is at the highest level of the development of moral self-regulation, which is a relatively adult and stable system. This causes more critical attitude towards oneself and others, demands for the moral image of peers and adults increase. Obviously, such 
transformations of consciousness lead to changes in the activities, behavior and relationships of the individual (Массанов, 2009). The spiritual self-determination of the young man takes place in the context of active development and the formation of moral consciousness. As L. Pylypenko (Пилипенко, 2011) proved, precisely interpersonal interaction is an important determinant of the development of spirituality in the adolescence.

One of the main characteristics of the teen-age and early adulthood is the change of meaningful individuals and the restructuring of the interpersonal interaction with adults. This is although significant for a young man, but does not involve full self-disclosure. V. Mukhina shows an accurate description of the process of reciprocal relations: «Acquiring the potential of the individual entering the second birth, youth begins to feel relieved from the direct dependence on a close circle of meaningful persons (friends and relatives). Such independence brings a bright experience, overflows emotionally and creates a huge amount of problems. In order to reach the understanding of the relativity of any independence, in order to appreciate the kinship and authority and the experience of the older generation, the youth must go through the spiritual path of the biblical prodigal son through the hard, unbearably difficult experiences of alienation from a circle of meaningful people, through the deep reflexive suffering and the search for true values to return in a new incarnation - now as an adult capable of identifying oneself with meaningful loved ones and now ultimately accepting them as they are» (Мухина, 1999: 422). The described process of alienation, through the torment of marginalization to rethinking, understanding and joining, is also true for interactions with peers. In this case, it proceeds in the opposite direction (Huang, Broniarczyk, Zhang \& Beruchashvili, 2015). Suchcomplex, emotionally saturated and absolutely opposite processes occur practically simultaneously in a relatively short period - during the teen-age.

The process of reconstructing interpersonal interaction with peers has some peculiarities. According to I. Bech, «The need for deep personal contact is particularly acute in the early youth, when the young people's desire for awareness of their individuality demands expression as a mirror (the other «I») and the expression of complicity. Probably, this can be explained by the craving of boys and girls to a friendly communication»(Бex, 1998: 83). I. Shyrshova (Ширшова, 1996) calls this period the peak in the development of the need for the interpersonal interaction. That is why the young men make a lot of effort to meet the needs of interpersonal interaction (Le, Impett, Lemay Jr. etc., 2018). At the same time the personal development of the young man will mostly depend on the choice of the way of his satisfaction and the result of his realization.

The development of value-semantic sphere in the personality of the teen-age creates a new, unknown for prior periods, differentiation of the interaction on relations friendship and romantic relationships (Pietrulewicz \& Zhuravlova, 2016). Increase of selectivity and the complication of the requirements for friendship suggests that a significant number of interpersonal interactions do not have their continuation, or remain at the level of coherent interaction (relationships).

Friendship takes a special place in the life of a teenager. It is the first self-chosen deep emotional attachment of the individual. It is typical for the teen-age friendship to have a high degree of mutual understanding, inner affinity and frankness. Its internalization allows us to maintain relations at a distance. This was impossible for earlier periods of ontogenesis. However, with the advent of love the emotional tension of friendship decreases (Кулагина, 2001). I. Кon 
(КоH, 1979) considers love as a specific form of the interpersonal interaction, which involves maximum intimacy and proximity. As we can see the most advanced forms of the interpersonal interaction become accessible to a person only from the teen-age.

The highest level of the interpersonal interaction, which is fully attained for the first time in the early youth, is not limited with a friendship and love relations. At the same level, there are antipodes - hatred, hostility etc. (Poteat, Mereish \& Birkett, 2015). V. Mukhina, describing the psychological peculiarities of the teen-age, calls the teen-age the time of «unflattering love and unrelenting hate» (Мухина, 1999: 421). The nature of early youth lies in such extremes and ambivalence. In the teen-age period individualhas the possibility of manifestation of the entire spectrum of possible forms of the interpersonal interaction.

The actualization of the needs in interpersonal relationships of the individual in the teenage contributes to the search and the development of various ways of its implementation. The effectiveness of the personal self-realization at all subsequent life stages depends on the choice of the strategy of the interpersonal interaction at this ageperiod.

\section{Research methods}

In order to determine the peculiarities of personality behavior in the situation of the interpersonal interaction, was used the FIRO-B Schutz technique, in its adapted Russianlanguage version, known as the «Fundamental Interpersonal Reiations Orientation (FIRO)» by A. Rukavishnikov (Рукавишников, 2003). This methodology diagnoses the behavior of a person in three parameters - the level of contact (behavioral) activity (scale «Inclusion»), the level of affectation (psychological closeness - scale «Effect») and the level of manifestations of dominance (power position - the scale «Control»). Each of the scales diagnoses five levels of the manifestation of the corresponding indicator: $0-1$ point - extremely low; 2-3 points - low; 4-5 points - average (boundary); 6-7 points - high; 8-9 points - extremely high. Each of the parameters involves two forms of behavior: active (own behavior towards other people) and passive (behavior of others towards itself). Such a versatility of the methodology makes it possible to carry out a detailed analysis of individual peculiarities of personality behavior in a situation of interpersonal interaction. Since the purpose of our study is to determine the behavior of boys, the indicators of their own activity were analyzed. The same activity indicators of others are omitted in this study.

Statistical processing of the results was performed with the help of the IBM SPSS Statistics software package. Specifically, the following statistical indicators were determined: average quantities, standard deviations, and Student $\mathrm{t}$-test for average quantities.

The study covered 226 young people (total sample). Among them, 110 respondents of early teen-age (51 male and 59 female) and 116 - adulthood (41 male and 74 female). In order to increase the level of representativeness of the sample, the study was conducted with representatives of various educational institutions of Zhytomyr region, studying in different areas. In particular, the pupils of Zhytomyr Ecological Lyceum (54 people), Teteriv secondary school of I-III degrees (20 people), students of Zhytomyr College of Construction (40 people), Zhytomyr Ivan Franko State University (38 people), Zhytomyr National Agroecological University (74 people) took part in the experiment. 


\section{Results and discussions}

In the process of the research of the behavioral aspect of the interpersonal interaction, it was determined that almost half of the subjects show a moderate interpersonal activity, indicating an adequate satisfaction of the need of modern youth in the interpersonal interaction (see Table 1). At the same time, almost a third of respondents demonstrate a high level of activity, and only sevenhalf has social and deficit behavior. Pathological and high behavioral activity is observed in five times more often than pathologically-low. Thus, we can state that the Other still remain an important part of the life of the modern young person and the teenager is disposed to adequate contact in the interaction with other people.

The analysis of the dynamic aspect of the interpersonal activity of young people made possible to state the tendency for its declining in the period of adulthood. Particularly, we observe a significant increase in the number of representatives $(t=2.60 ; p \leq 0.05)$ of the researched group with the contact deficit during the decrease in the number of people who are actively involved in interpersonal interactions. Such results prove the above mentioned principle empirically, which is associated with increasingthe selectivity and demanding to interpersonal interaction partners. On the one hand, these processes are determined by the active development of moral consciousness that is peculiar at this age stage and it causes an increase of moral requirements for the behavior of the Other, and, on the other hand - the growth of self-worth, caused by the active development of self-consciousness.

Table 1

Gender and dynamic indicators of the interpersonal interaction activity

\begin{tabular}{|c|c|c|c|c|c|c|c|c|c|c|}
\hline \multicolumn{2}{|c|}{ Age } & \multicolumn{3}{|c|}{$15-21$} & \multicolumn{3}{c|}{$15-17$} & \multicolumn{3}{c|}{$18-21$} \\
\hline \multicolumn{2}{|c|}{ Gender } & Both & B & G & Both & B & G & Both & B & G \\
\hline \multirow{3}{*}{ Pathologically low } & $\%$ & 0.9 & 1.1 & 0.7 & 0.9 & 0.0 & 1.7 & 0.9 & 2.4 & 0.0 \\
\cline { 2 - 13 } & $\overline{\mathbf{x}}$ & 1.0 & 1.0 & 1.0 & 1.0 & - & 1.0 & 1.0 & 1.0 & - \\
\hline \multirow{3}{*}{ Deficit } & $\%$ & 13.7 & 16.1 & 12.0 & 10.0 & 9.8 & 10.2 & 17.2 & 23.8 & 14.6 \\
\cline { 2 - 13 } & $\overline{\mathbf{x}}$ & 2.8 & 2.7 & 2.9 & 2.8 & 2.6 & 3.0 & 2.8 & 2.8 & 2.8 \\
\hline \multirow{3}{*}{ Ideal } & $\%$ & 53.1 & 44.1 & 59.4 & 52.7 & 45.1 & 59.3 & 53.4 & 42.8 & 59.4 \\
\cline { 2 - 12 } & $\overline{\mathbf{x}}$ & 4.6 & 4.7 & 4.6 & 4.6 & 4.6 & 4.6 & 4.7 & 4.7 & 4.7 \\
\hline \multirow{3}{*}{ High } & $\%$ & 27.4 & 35.5 & 21.8 & 31.8 & 43.1 & 22.0 & 23.3 & 26.2 & 21.6 \\
\cline { 2 - 11 } & $\overline{\mathbf{x}}$ & 6.2 & 6.2 & 6.3 & 6.1 & 6.1 & 6.1 & 6.4 & 6.4 & 6.4 \\
\hline \multirow{2}{*}{ Pathologically high } & $\%$ & 4.9 & 3.2 & 6.1 & 4.6 & 2.0 & 6.8 & 5.2 & 4.8 & 5.4 \\
\cline { 2 - 11 } & $\mathbf{x}$ & 8.2 & 8.3 & 8.1 & 8.2 & 8.0 & 8.2 & 8.2 & 8.5 & 8.0 \\
\hline
\end{tabular}

Notes: $\mathrm{B}$ - boys, $\mathrm{G}$ - girls, Both - together; $\overline{\mathbf{x}}$ - average indicator.

If we talk about gender characteristics, we can state that more intense dynamics of selfactivityof the interpersonal interaction is observedin the representatives of the male sample during the youth, compared with the female.

In particular, in adulthood, the number of boys with deficient (low) activity increases more than twice compared to the early age, which is due to a decrease in the number of boys 
with a high level $(\mathrm{t}=2.04 ; \mathrm{p} \leq 0.05)$. Girls' age dynamics is rather small (fluctuations of indicators within five percent). At the same time, it should be noted that in the period of early youth, a higher level of interpersonal activity was found in men, and in adulthood - in women.

The research of the peculiarities of the interpersonal interaction affection has shown that teen-age is characterized by the whole spectrum of possible activities: from excessive emotionality to complete indifference (see Table 2). Particularly, about a quarter of the total sample subjects show a high and almost the same level of emotionality, the fifth part - a deficit level, and sixth and tenth parts of the respondents show pathologically high and pathologically low levels.

These indicators are not the same throughout the teen-age period. If in the teen-age tendencies are saved, thus, in a sample of representatives of adulthoodthey are accompanied by a significant decrease in the number of people with a high level of affectation to the interaction with an increase of almost twice the number of subjects with a pathologically high level. So, the percentage of the representatives of different levels of emotionality in the situation of the interpersonal interaction (except pathologically low) varies within $2.5 \%$. At the same time we can talk about the tendency of increasing the pathological indicators of emotionality in the interaction in the period of adulthood, which we regard as a consequence of youth maximalism.

Table 2

Gender and dynamic indicators of the interpersonal interaction activity

\begin{tabular}{|c|c|c|c|c|c|c|c|c|c|c|}
\hline \multicolumn{2}{|c|}{ Age } & \multicolumn{3}{|c|}{$15-21$} & \multicolumn{3}{c|}{$15-17$} & \multicolumn{3}{c|}{$18-21$} \\
\hline \multirow{2}{*}{ Gender } & Both & B & G & Both & B & G & Both & B & G \\
\hline \multirow{3}{*}{ Pathologically low } & $\%$ & 11.1 & 6.4 & 14.3 & 10.0 & 2.0 & 17.0 & 12.1 & 11.9 & 12.1 \\
\cline { 2 - 12 } & $\overline{\mathbf{x}}$ & 0.6 & 0.5 & 0.7 & 0.8 & 1.0 & 0.8 & 0.5 & 0.4 & 0.6 \\
\hline \multirow{3}{*}{ Deficit } & $\%$ & 20.3 & 18.3 & 21.8 & 17.3 & 13.7 & 20.3 & 23.3 & 23.8 & 23.0 \\
\cline { 2 - 12 } & $\overline{\mathbf{x}}$ & 2.5 & 2.5 & 2.5 & 2.6 & 2.6 & 2.6 & 2.5 & 2.5 & 2.5 \\
\hline \multirow{3}{*}{ Ideal } & $\%$ & 23.9 & 29.0 & 20.3 & 26.4 & 29.4 & 23.7 & 21.5 & 28.6 & 17.6 \\
\cline { 2 - 11 } & $\overline{\mathbf{x}}$ & 4.5 & 4.6 & 4.4 & 4.5 & 4.7 & 4.4 & 4.4 & 4.4 & 4.4 \\
\hline \multirow{3}{*}{ High } & $\%$ & 28.3 & 24.7 & 30.8 & 34.5 & 37.2 & 32.2 & 22.4 & 9.5 & 29.7 \\
\cline { 2 - 11 } & $\overline{\mathbf{x}}$ & 6.5 & 6.6 & 6.4 & 6.5 & 6.6 & 6.4 & 6.5 & 6.7 & 6.4 \\
\hline \multirow{3}{*}{ Pathologically high } & $\%$ & 16.4 & 21.5 & 12.8 & 11.8 & 17.7 & 6.8 & 20.7 & 26.2 & 17.6 \\
\cline { 2 - 11 } & $\overline{\mathbf{x}}$ & 8.3 & 8.2 & 8.5 & 8.2 & 8.2 & 8.2 & 8.4 & 8.3 & 8.5 \\
\hline
\end{tabular}

Notes: $\mathrm{B}$ - boys, $\mathrm{G}$ - girls, Both - together; $\overline{\mathbf{x}}$ - average indicator.

The analysis of gender differences has shown that for boys the more appropriate is the adequate level of the affectation, and young girls are characterised by the high level. The least characteristic level for boys is the pathologically low level of emotionality, and it is pathologically high for girls.

The research of dominance in the behavior of youth has shown that most of the subjects has an adequate level, and one third of themis characterized by autocratic and abductive types of 
behavior (see Table 3). Pathologically high level of dominance is observed in every twelfth person of the teen-age. A characteristic feature of the teen-age is rather a high rate of pathologically high domination (10.9\%), which is as twice as in adulthood.

Speaking about the gender characteristics of dominance, it is worth paying attention to the fact that in general, girls demonstrate their dominance more often than boys. Moreover, this tendency is more distinct in the teen-age than in adulthood. Thus, one tenth of boys and every fifth girl (twice as likely) show a high level of dominance at the teen-age, and each seventeenth boy and sixth girl demonstrate pathologically high (three times as likely). The number of girls with pathologically high indicators of dominance in adulthood decreases almost threefold, due to which gender differentiation at this level disappears.

Thus, another peculiarity of the behavioral component was established: in the period of youth, the girls experience more intense dynamics of dominance, compared to the boys.

Table 3

Gender and dynamic indicators of the interpersonal interaction activity

\begin{tabular}{|c|c|c|c|c|c|c|c|c|c|c|}
\hline \multicolumn{2}{|c|}{ Age } & \multicolumn{3}{|c|}{$15-21$} & \multicolumn{3}{c|}{$15-17$} & \multicolumn{3}{c|}{$18-21$} \\
\hline \multicolumn{2}{|c|}{ Gender } & Both & B & G & Both & B & G & Both & B & G \\
\hline \multirow{3}{*}{ Pathologically low } & $\%$ & 0.9 & 1.1 & 0.8 & - & - & - & 1.7 & 2.4 & 1.3 \\
\cline { 2 - 12 } & $\overline{\mathbf{x}}$ & 1.0 & 1 & 1.0 & - & - & - & 1.0 & 1.0 & 1.0 \\
\hline \multirow{3}{*}{ Deficit } & $\%$ & 15.9 & 17.2 & 15.0 & 17.3 & 19.6 & 15.3 & 14.6 & 14.3 & 14.9 \\
\cline { 2 - 12 } & $\overline{\mathbf{x}}$ & 2.6 & 2.6 & 2.5 & 2.4 & 2.5 & 2.2 & 2.8 & 2.8 & 2.8 \\
\hline \multirow{3}{*}{ Ideal } & $\%$ & 58.8 & 66.7 & 53.4 & 55.4 & 64.7 & 47.4 & 62.1 & 69.0 & 58.1 \\
\cline { 2 - 11 } & $\overline{\mathbf{x}}$ & 4.5 & 4.5 & 4.6 & 4.6 & 4.4 & 4.7 & 4.5 & 4.5 & 4.5 \\
\hline \multirow{3}{*}{ High } & $\%$ & 16.4 & 9.7 & 21.0 & 16.4 & 9.8 & 22.0 & 16.4 & 9.5 & 20.3 \\
\cline { 2 - 11 } & $\overline{\mathbf{x}}$ & 6.2 & 6.3 & 6.2 & 6.3 & 6.4 & 6.3 & 6.2 & 6.2 & 6.1 \\
\hline \multirow{2}{*}{$\begin{array}{c}\text { Pathologically } \\
\text { high }\end{array}$} & $\%$ & 8.0 & 5.3 & 9.8 & 10.9 & 5.9 & 15.3 & 5.2 & 4.8 & 5.4 \\
\cline { 2 - 10 } & $\overline{\mathbf{x}}$ & 8.6 & 8.6 & 8.5 & 8.4 & 8.3 & 8.4 & 8.8 & 9.0 & 8.7 \\
\hline
\end{tabular}

Notes: $\mathrm{B}$ - boys, $\mathrm{G}$ - girls, Both - together; $\overline{\mathbf{x}}$ - average indicator.

\section{Conclusions}

1. In general, modern boys are characterized by adequate satisfaction of their own needs in the interpersonal interaction. In the period from the teen-age to adulthood, there is a decrease in the level of social contact of young people. This dynamics is more intense for boys, compared to girls.

2. Adolescence express emotions in the process of the interpersonal interaction in different ways: from pathological emotionality to complete indifference. The is a tendency of increasing of pathological indicators of emotionality in the interaction during the period of adulthood. Boys mostly show an adequate level of emotional activity, and for girls it is high.

3 . In general, modern youth tends to adequately satisfy their own need for dominance in the process of the interaction with others. However, in the teen-age, characteristics of dominant behavior are much more frequent than in the adulthood. Boys are inferior to the level of 
dominance compared to girls. We see the prospects for further research in the study of interpersonal interaction at other stages of ontogeny.

\section{Literature}

1. Ináncsi, T., Láng, A., \& Bereczkei, T. (2015). Machiavellianism and adult attachment in general interpersonal relationships and close relationships. Europe's journal of psychology, 11(1), 139.

2. Huang, S.C., Broniarczyk, S.M., Zhang, Y., \& Beruchashvili, M. (2015). From close to distant: The dynamics of interpersonal relationships in shared goal pursuit. Journal of Consumer Research, 41(5), 1252-1266.

3. Le, B.M., Impett, E.A., Lemay Jr,E.P., Muise, A., \& Tskhay, K.O. (2018). Communal motivation and well-being in interpersonal relationships: An integrative review and metaanalysis. Psychological bulletin, 144(1), 1.

4. Pietrulewicz, B., \& Zhuravlova, L. (2016). Significance of relationships and psychosocial adaptation during adolescence. Science and Education, 5, 7-29. Режим доступу: https://scienceandeducation.pdpu.edu.ua/uk/articles/2016-5-doc/2016-5-st3

5. Poteat, V.P., Mereish, E.H., \& Birkett, M. (2015). The negative effects of prejudice on interpersonal relationships within adolescent peer groups. Developmental psychology, 51(4), 544.

6. Orehek, E., Forest, A.L., \& Barbaro, N. (2018). A people-as-means approach to interpersonal relationships. Perspectives on Psychological Science, 13(3), 373-389.

7. Verny, T.R., \& Kelly, J. (1988). The secret life of the unborn child. Dell, 253.

8. Бех, І.Д. (2008). Виховання особистості: Підручник. Київ: Либідь, 848.

9. Бех, І.Д. (1998). Особистісно зорієнтоване виховання. Київ: ІЗМН.

10. Божович, Л.И. (1968). Личность и ее формирование в детском возрасте. Москва: Просвещение.

11. Боришевський, М.Й. (Ред.). (2006). Психологічні закономірності розвитку громадянської спрямованості особистості: монографія. Київ: Міленіум.

12. Будур, I.M. (2009). Проблема формування згуртованості в психології. Наукові записки Харківського університету повітряних сил. Соціальна філософія, психологія, 2 (33), 214-221.

13. Сгурская, Л.В., \& Тамарский, Г.С. (2003). Диагностика межличностных отношений подростков и старшеклассников: Методические рекомендации. Калининград: Изд-во КГУ.

14. Кон, И.С. (1979). Психология юноческого возраста: (Проблемь фоормирования личности). М.: Просвещение.

15. Кулагина, И.Ю., \& Колюцкий В.Н (2001). Возрастная психология: полный жизненный цикл развития человека. Москва: ТЦ «Сфера».

16. Массанов, А.В. (2009). Психологічний супровід удосконалення особистості майбутніх фахівців. Наука і освіта, 5, 94-98.

17. Мухина, В.С. (1999). Возрастная психология: феноменология развития, детство, отрочество: учебник для студентов вузов. М.: Издательский центр «Академия».

18. Пилипенко, Л.І. (2011). Самовизначення особистості в міжособистісних взаєминах як фактор розвитку ії духовності. Збірник наукових пращь Інституту психологї імені Г.С. Костюка Начіональної АПН України, XIII, ч. 4, 267-274.

19. Самоукина, Н. (2000). Симбиотические аспекты отношений между матерью и ребенком. Вопросы психологии, 3, 67-81.

20. Ширшова, И.А. (1996). Развитие гуманистических убеждений старшеклассников в межсличностных отношениях (Дисс. канд. психол. наук.). Москва.

\section{References}

1. Ináncsi, T., Láng, A., \& Bereczkei, T. (2015). Machiavellianism and adult attachment in general interpersonal relationships and close relationships. Europe's journal of psychology, 11(1), 139. 
2. Huang, S.C., Broniarczyk, S.M., Zhang, Y., \& Beruchashvili, M. (2015). From close to distant: The dynamics of interpersonal relationships in shared goal pursuit. Journal of Consumer Research, 41(5), 1252-1266.

3. Le, B.M., Impett, E.A., Lemay Jr, E.P., Muise, A., \& Tskhay, K.O. (2018). Communal motivation and well-being in interpersonal relationships: An integrative review and metaanalysis. Psychological bulletin, 144(1), 1.

4. Pietrulewicz, B., \& Zhuravlova, L. (2016). Significance of relationships and psychosocial adaptation during adolescence. Science and Education, 5, 7-29. Retrieved from https://scienceandeducation.pdpu.edu.ua/uk/articles/2016-5-doc/2016-5-st3

5. Poteat, V.P., Mereish, E.H., \& Birkett,M. (2015). The negative effects of prejudice on interpersonal relationships within adolescent peer groups. Developmental psychology, 51(4), 544.

6. Orehek, E., Forest, A.L., \& Barbaro, N. (2018). A people-as-means approach to interpersonal relationships. Perspectives on Psychological Science, 13(3), 373-389.

7. Verny, T.R., \& Kelly, J. (1988). The secret life of the unborn child. Dell, 253.

8. Bekh, I.D. (2008) Vykhovannia osobystosti [Personal education]. Kyiv : Lybid [in Ukrainian].

9. Bekh, I.D. (1998) Osobystisno zoriientovane vykhovannia [Personally oriented education]. Kyiv : IZMN [in Ukrainian].

10. Bozhovich, L.I. (1968). Lichnost' i ee formirovanie $\mathrm{v}$ detskom vozraste [Personality and its formation in childhood]. Moscow : Prosveshhenie [in Russian].

11. Borishevs'kij, M.J. (Ed.). (2006). Psihologichni zakonomirnosti rozvitku gromadyans'koï spryamovanosti osobistosti: monografiya [Psychological patterns of development of civic orientation of the individual: a monograph]. Kyiv : Milenium [in Ukrainian].

12. Budur, I.M. (2009). Problema formuvannia zghurtovanosti v psykholohii. Naukovi zapysky Kharkivskoho universytetu povitrianykh syl. Sotsialna. filosofiia, psykholohiia - Scientific notes of Kharkiv Air Force University. Social philosophy, psychology, 2 (33), 214-221. [in Ukrainian].

13. Sgurskaja, L.V., \& Tamarskij, G.S. (2003). Diagnostika mezhlichnostnyh otnoshenij podrostkov $i$ starsheklassnikov: Metodicheskie rekomendacii [Diagnosis of interpersonal relationships of adolescents and high school students: Guidelines]. Kaliningrad : Izd-vo KGU [in Russian].

14. Kon, I.S. (1979). Psihologija junosheskogo vozrasta: (Problemy formirovanija lichnosti) [Psychology of adolescence: (Problems of personality formation]. Moscow : Prosveshhenie [in Russian].

15. Kulagina, I. Ju., \& Koljuckij, V. N. (2001). Vozrastnaja psihologija: polnyj zhiznennyj cikl razvitija cheloveka: uchebnoe posobie dlja studentov vysshih uchebnyh zavedenij [Age psychology: the complete life cycle of human development]. Moscow : TC «Sfera» [in Russian].

16. Massanov, A.V. (2009). Psihologichnij suprovid udoskonalennja osobistosti majbutnih fahivciv [Psychological support for improving the personality of future professionals]. Nauka i osvita - Science and Education, № 5, 94-98 [in Ukrainian].

17. Muhina, V.S. (1999). Vozrastnaja psihologija: fenomenologija razvitija, detstvo, otrochestvo: uchebnik dlja stud. vuzov [Age psychology: phenomenology of development, childhood, adolescence: textbook for university students]. Moscow : Izdatel'skij centr «Akademija» [in Russian].

18. Pylypenko, L.I. (2011). Samovyznachennia osobystosti v mizhosobystisnykh vzaiemynakh yak faktor rozvytku yii dukhovnosti [Self-determination of personality in interpersonal relationships as a factor in the development of its spirituality]. Zbirnyk naukovykh prats Instytutu psykholohii imeni H.S. Kostiuka Natsionalnoi APN Ukrainy - Proceedings of the GS Psychology Institute Kostyuk of the National APS of Ukraine, T.XIII, 4, 267-274 [in Ukrainian].

19. Samoukina, N. (2000). Simbioticheskie aspekty otnoshenij mezhdu mater'ju i rebenkom [Symbiotic aspects of mother-child relationships.]. Voprosy psihologii - Psychology issues, №3, 67-81 [in Russian]. 
20. Shirshova, I.A. (1996). Razvitie gumanisticheskih ubezhdenij starsheklassnikov v mezhlichnostnyh otnoshenijah [Development of humanistic beliefs of high school students in interpersonal relations]. Candidate's thesis. Moscow [in Russian].

\section{ПСИХОЛОГІЧНІ ОСОБЛИВОСТІ МІЖОСОБИСТІСНОЇ ВЗАєМОДІЇ В ЮНАЦЬКОМУ ВІЦІ Лариса Журавльова \\ доктор психологічних наук, професор, завідувач кафедри психології розвитку та консультування \\ Житомирський державний університет імені Івана Франка 10001, Україна, м. Житомир, вул. Велика Бердичівська, 40 1pz2008@ukr.net, https://orcid.org/0000-0003-4020-7279}

Тетяна Коломісць кандидат психологічних наук, доцент, доцент кафедри психології розвитку та консультування

Житомирський державний університет імені Івана Франка 10001, Україна, м. Житомир, вул. Велика Бердичівська, 40 tvkolomiets@ukr.net, http://orcid.org/0000-0002-6883-8796

\section{Оксана Шмиглюк}

асистент кафедри психології розвитку та консультування

Житомирський державний університет імені Івана Франка 10001, Україна, м. Житомир, вул. Велика Бердичівська, 40 shmyglyuk.oksana@gmail.com, http://orcid.org/0000-0002-3334-8033

\section{Анотація}

Метою дослідження є вивчення психологічних особливостей поведінки юнаків в умовах міжособистісної взаємодії. Для реалізації дослідницьких завдань застосовано теоретичні, емпіричні та статистичні методи. У статті подано основні результати емпіричного дослідження поведінкової активності, афектації й проявів домінантності юнаків у ситуації міжособистісної взаємодії. Проаналізовано їх вікові, статеві та динамічні особливості.

У результаті емпіричного дослідження 3'ясовано, що переважна більшість сучасного юнацтва проявляє помірну активність у встановленні міжособистісних контактів. Виявлено вікову динаміку міжособистісної взаємодії та проаналізовано піi статеві особливості. В період від ранньої до зрілої юності відбувається зниження рівня соціальної контактності молоді. У хлопців дана динаміка $\epsilon$ більш інтенсивною, порівняно 3 дівчатами. Зафіксовано, що у період ранньої юності більш високий рівень міжособистісної активності $є$ в юнаків, а у зрілій юності - в юнок. Констатовано, що особи юнацького віку по-різному проявляють емоції у процесі міжособистісної взаємодії: від патологічної емоційності до повної байдужості. Виявлено тенденцію до зростання патологічних показників емоційності у взаємодії в період зрілої юності. Дана динаміка більш вираженою є у представників чоловічої статі, порівняно з жіночою. Емпірично доведено, що для юнаків більшою мірою притаманним є адекватний рівень емоційної активності, а для юнок - високий. Встановлено, що у переважній більшості сучасне юнацтво схильне адекватно задовольняти власну потребу в домінантності у процесі взаємодії з іншим. У ранній юності прояви домінантної поведінки є значно частішими ніж у зрілій, а хлопці поступаються у рівні домінантності дівчатам.

Ключові слова: афектація міжособистісної взаємодії, домінантність, контактність, міжособистісна взаємодія, юнацький вік. 